\title{
ANALISIS PENGARUH RASIO KEUANGAN TERHADAP RETURN SAHAM PADA PERUSAHAAN CONSUMER GOODS YANG TERDAFTAR DI BURSA EFEK INDONESIA TAHUN 2012-2014
}

\author{
Fitri Amalia Azzahra \\ fitriazzahra23@yahoo.co.id \\ Universitas Ahmad Dahlan \\ Aftoni Sutanto \\ aftoni@yahoo.com \\ Universitas Ahmad Dahlan
}

\begin{abstract}
ABSTRAK
This study is entitled Analysis of the Effect of Financial Financial Ratios on Stock Returns on Consumer Goods Companies Listed on the Indonesia Stock Exchange in 20122014. The purpose of this study is to determine whether the variable Current ratio (CR), Debt to Equity Ratio (DER), Earning per Share (EPS), and Total Asset Turn Over (TATO) affect the stock return. The analytical tool used is multiple linear regression, $t$ test, $F$ test, and R2. T test results prove that the CR variable has no effect on stock returns with a probability value of 0.9755 , the DER variable has no effect on stock returns with a probability value of 0.9442 , the EPS variable has an effect on stock returns with a probability value of 0.0049 , and TATO has no effect on stock returns with a probability value of 0.9809 . The test results with the F test prove that the variables CR, DER, EPS, and TATO simultaneously have no effect on stock returns with a probability value of 0.050589 . The R2 test result, 0.278689 , shows that the dependent variable of stock returns can be explained by the independent variables CR, DER, EPS, and TATO by $27.8 \%$ while the remaining $72.2 \%$ is explained by other variables not examined in this study.
\end{abstract}

Keywords: Current Ratio; Debt to Equity Ratio; Earning per Share; Total Asset Turn Over; Stock Returns.

\begin{tabular}{l}
\hline PENDAHULUAN \\
Perkembangan perekonomian \\
Indonesia tidak lepas dari adanya pasar \\
modal yang selalu aktif dalam \\
menggerakkan perekonomian Indonesia \\
dan memiliki daya tarik bagi banyak pihak \\
khusunya para pembisnis yang ingin \\
menjadikannya sebagai alternatif sumber \\
pembiayaan usaha. Dengan adanya pasar \\
modal memberikan keuntungan kepada \\
para pemodal untuk membentuk portofolio \\
investasi yang diharapkan dapat \\
memberikan keuntungan lebih dan dapat \\
menanggung risiko yang mungkin terjadi. \\
Perkembangan pasar modal dari \\
tahun ke tahun mengalami kenaikan. \\
Dengan adanya perubahan yang terdapat di
\end{tabular}

dalamnya hingga adanya Bursa Efek Indonesia. Aktivitas yang dilakukan sangat menguntungkan bagi para investor dan perusahaan untuk melakukan transaksi ekonomi. Untuk melakukan investasi saham, investor selalu mengharapkan return yang akan diperoleh. Oleh karena itu return saham sangat penting bagi perusahaan untuk menjadikan alat ukur kinerja perusahaan sehingga perusahaan selalu berusaha untuk menjaga dan memperbaiki kinerja perusahaan agar selalu meningkat.

Pasar modal diartikan sebagai pasar untuk berbagai instrumen keuangan (surat berharga) jangka panjang (usia jatuh temponya lebih dari 1 tahun) (Susilo, 2009). Pasar modal (capital market) didefinisikan sebagai perdagangan 
instrumen keuangan (sekuritas) jangka panjang, baik dalam bentuk modal sendiri (stock) maupun hutang (bonds), baik yang diterbitkan oleh pemerintah (public authorities) maupun oleh perusahaan swasta (private sector) (Untung, 2011).

Menurut Hanafi (2004) laporan keuangan perusahaan bertujuan untuk meringkaskan kegiatan dan hasil dari kegiatan tersebut untuk jangka panjang waktu tertentu, laporan keuangan menjadi penting karena memberikan input (informasi) yang bisa dipakai untuk pengambilan keputusan karena banyak pihak yang berkepentingan terhadap laporan keuangan, mulai dari investor atau calon investor, pihak pemberi dana atau calon pemberi dana, sampai pada manajemen perusahaan itu sendiri. Laporan keuangan diharapkan memberikan informasi mengenai profitabilitas, risiko, dan timing, dari aliran kas yang dihasilkan perusahaan yang nantinya akan mempengaruhi pihakpihak yang berkepentingan dan pada giliran selanjutnya akan mempengaruhi nilai perusahaan. Menurut Penman (1991) dalam Ulupui (2005), laporan keuangan merupakan sebuah informasi yang sangat penting bagi investor dalam mengambil keputusan investasi. Laporan keuangan tersebut menjadi optimal bagi investor apabila investor dapat menganalisis lebih lanjut melalui analisis rasio keuangan.

Horigan (1965) dalam Ulupui (2005), menyatakan bahwa rasio keuangan berguna untuk memprediksi kesulitan keuangan perusahaan, hasil operasi, kondisi keuangan perusahaan saat ini dan pada masa mendatang, serta sebagai pedoman bagi investor mengenai kinerja masa lalu dan masa mendatang. Analisis rasio keuangan merupakan dasar untuk menilai dan 3 menganalisa prestasi operasi perusahaan. Di samping itu, analisis rasio keuangan juga dapat dipergunakan sebagai kerangka kerja perencanaan dan pengendalian keuangan (Sartono, 1997). Dengan menganalisis rasio keuangan maka akan diperoleh informasi keuangan perusahaan dimana memberikan pengaruh kelemahan dan kekuatan suatu perusahaan dan digunakan perusahaan untuk membuat keputusan di masa yang akan datang, selain itu dapat dipergunakan investor untuk menjadi pertimbangan saat ingin menanamkan dananya pada perusahaan melalui pasar modal.

\section{Rumusan Masalah}

1. Apakah current ratio (CR) berpengaruh terhadap return saham pada perusahaan Consumer Goods Industry yang tercatat di Bursa Efek Indonesia tahun 20122014 ?

2. Apakah debt to euity ratio (DER) berpengaruh terhadap return saham pada perusahaan Consumer Goods Industry yang tercatat di Bursa Efek Indonesia tahun 2012-2014?

3. Apakah earning per share (EPS) berpengaruh terhadap return saham pada perusahaan Consumer Goods Industry yang tercatat di Bursa Efek Indonesia tahun 2012-2014?

4. Apakah total asset turnover (TATO) berpengaruh terhadap return saham pada perusahaan Consumer Goods Industry yang tercatat di Bursa Efek Indonesia tahun 2012-2014?

5. Apakah rasio keuangan yang terdiri dari CR, DER, EPS, dan TATO berpengaruh secara simultan terhadap return saham pada perusahaan Consumer Goods Industry yang tercatat di Bursa Efek Indonesia tahun 2012-2014?

\section{REVIEW LITERATUR DAN HIPOTESIS}

\section{Landasan Teori \\ Laporan Keuangan}

Laporan keuangan merupakan hasil akhir dari proses akuntansi. Laporan keuangan memuat informasi tentang pelaksanaaan tanggung jawab manajemen. Dengan demikian, laporan keuangan adalah sepenuhnya tanggung jawab dari mananjemen yang merupakan pertanggungjawaban atas kewenangan 
mengelola sumber daya perusahaan yang diserahkan oleh pemilik (Darsono dan Ashari, 2004). Laporan keuangan adalah hasil dari proses akuntansi yang dapat digunakan sebagai alat untuk berkomunikasi antara data keuangan atau aktivitas suatu perusahaan dengan pihakpihak yang berkepentingan dengan data atau aktivitas perusahaan tersebut.

Laporan keuangan pada dasarnya bertujuan untuk mencatat semua hasil kegiatan perusahaan untuk jangka waktu kedepan agar perusahaan mudah untuk mengambil keputusan. Laporan keuangan dapat dipakai untuk memberikan informasi mengenai profitabilitas, risiko, dan timing dari aliran kas yang dihasilkan perusahaan.

\section{Pasar Modal}

Pasar modal adalah sarana atau tempat untuk bertransaksi antar pihak pemodal dengan perusahaan. Bagi para investor pasar modal merupakan tempat mereka untuk saling bertransaksi menginvestasikan dananaya. Pasar modal memiliki peran bagi perekonomian negara yaitu sarana bagi para investor untuk menginvestasikan dananaya pada perusahaan dan menjadikan sarana untuk berinvestasi bagi masyarakat untuk instrumen keuangan. Menurut (Martalena dan Malinda, 2011) pasar modal (capital market) merupakan pasar untuk berbagai instrumen keuangan jangka panjang yang bisa diperjualbelikan, baik surat utang (obligasi), ekuisis (saham), raksadana, instrumen derivatif maupun instrumen lainnya. Instrumen keuangan yang diperdagangkan di pasar modal merupakan instrumen jangka panjang (jangka12 waktu lebih dari 1 tahun) seperti saham, obligasi, waran, righ, reksadana dan berbagai instrumen derivatif seperti option, future, dan lain lain.

Menurut (Untung, 2011) pasar modal merupakan konsep yang lebih sempit dari pasar keuangan (finansial market). Dalam finansial market, diperdagangkan semua bentuk hutang dan modal sendiri, baik dana jangka pendek maupun jangka panjang, baik yang bersifat negotiable maupun yang nonnegotiable. Dalam menjalankan fungsi ekonomi, pasar modal menyediakan fasilitas untuk memindahkan dana dari pihak yang memiliki kelebihan dana (lenders) ke pihak yang memerlukan dana (borrowers). Dengan menginvestasikan kelebihan dana yang mereka miliki, lenders berharap akan memperoleh imbalan dari penyerahan dana tersebut. Sedangkan borrowers akan menggunakan dana tersebut untuk kepentingan investasi tanpa harus menunggu tersedianya dana dari operasi perusahaan.

Sedangkan pasar modal menurut undang-undang merupakan kegiatan yang berhubungan dengan penawaran umum dan perdagangan efek, perusahaan publik yang berkaitan dengan efek yang diterbitkannya, serta lembaga dan profesi yang berkaitan dengan efek. (Bab 1, pasal 1, angka 13, UURI no 8, 1995 tentang pasar modal)

\section{Saham}

Saham merupakan bukti kepemilikan suatu perusahaan. Pemegang saham memperoleh pendapatan dari dividen dan capital gain (selisih antar14 harga jual dengan harga beli) (Hanafi, 2004). Menurut Asakdiyah (2007), saham dibagi mejadi 2 jenis:

\section{Return Saham}

Return saham adalah pendapatan yang dinyatakan dalam presentase dari modal awal investasi. Pendapatan dalam investasi dalam saham ini meliputi keuntungan jual beli saham, di mana jika untung disebut capital gaindan jika rugi disebut capital loss. Di samping capital gain, investor juga akan menerima dividen tunai setiap tahunnya. Emiten akan membagikan dividen tunai dua kali setahun, di mana yang pertama disebut dividen interim yang dibayarkan selama tahun berjalan, sedangkan yang kedua disebut dividen final yang dibagikan setelah tutup tahun buku (Samsul, 2006). 
Menurut (Jogiyanto, 2014) Return merupakan hasil yang diperoleh dari investasi.

\section{Rasio Keuangan}

Rasio menggambarkan suatu hubungan atau perimbangan (mathematichal relationship) antara suatu jumlah tertentu dengan jumlah yang lain, dan dengan menggunakan alat analisa berupa rasio ini akan dapat menjelaskan atau memberi gambaran kepada penganalisa tentang baik atau buruknya keadaan atau posisi keuangan suatu perusahaaan (Munawir, 1998).

Analisis rasio keuangan merupakan dasar untuk menilai dan menganalisa prestasi operasi perusahaan. Di samping itu, analisis rasio keuangan juga dapat dipergunakan sebagai kerangka kerja perencanaan dan pengendalian keuangan (Sartono, 1997). Menurut Alwi (1992) dalam Asakdiyah (2006) rasio merupakan alat bantu yang dinyatakan dalam artian relatif atau absolut untuk menjelaskan hubungan tertentu antara angka yang21 satu dengan yang lain suatu laporan keuangan. Sedangkan analisis rasio merupakan bentuk atau cara yang umum digunakan dalam analisis laporan finansial (keuangan). Rasio ini dapat dihitung berdasarkan laporan keuangan yang meliputi: (1) Balance sheet atau neraca yang menunjukkan posisi keuangan perusahaan pada suatu saat, dan (2) income statment (laporan rugi laba) yang merupakan laporan operasi selama periode tertentu.

\section{Penelitian Terdahulu}

a. Riyani (2011) meneliti dengan judul "Analisis Pengaruh Rasio Profitabilitas Terhadap Return Saham Pada Perusahaan LQ45 yang Terdaftar di Bursa Efek Indonesia”. Pada penelitian ini bertujuan untuk mengetahui pengaruh Return On Asset (ROA), Return On Equity (ROE), Earning Per Share (EPS), Net Profit Margin (NPM), dan Gross Profit Margin (GPM) terhadap return saham. Dari pengujian uji-t diperoleh hasil bahwa secara parsial variabel independen ROA, dan NPM berpengaruh signifikan terhadap return saham. Sedangakan variabel ROE, EPS, dan GPM tidak berpengaruh signifikan terhadap return saham.

Berdasarkan hasil uji-F variabel ROA, ROE, EPS, NPM, dan GPM secara serempak tidak berpengaruh signifikan terhadap return saham.

b. Ulupui (2005) meneliti dengan judul "Analisis Pengaruh Rasio Likuiditas, Leverage, Aktivitas, dan Profitabilitas Terhadap Return Saham". Dari ujiF diperoleh bahwa variabel independen current ratio, debt to equity ratio, asset turn over, dan return on asset secara simultan berpengaruh signfikan terhadap return saham satu tahun ke depan. Dari hasil pengujian uji-t diperoleh hasil bahwa variabel current ratio dan return on asset berpengaruh signifikan terhadap retun saham sedangkan rasio asset turn over dan debt to equity tidak berpengaruh signifikan terhadap retun saham satu tahun ke depan.

c. Anastasia (2011) meneliti dengan judul "Pengaruh Kinerja Keuangan Terhadap Return Saham Pada Perusahaan yang Terdaftar di LQ45 Selama Tahun 20062008" dengan variabel independen Current Ratio (CR), Quick Ratio (QR), Debt to Equity Ratio (DER), Return On Equity (ROE), Return26 on Total Asset (ROA), Total Asset Turnover (TAT), Earning Per Share (EPS), dan Price Earning Ratio (EAR) terhadap return saham. Dari hasil pengujian uji-t diperoleh hasil variabel CR, QR, DER, ROE, ROA, TAT, EPS tidak berpengaruh signifikan terhadap return saham sedangkan variabel PER berpengaruh signifikan terhadap return saham. Dan hasil pengujian uji-F menunjukkan variabel $\mathrm{CR}, \mathrm{QR}, \mathrm{DER}$, ROE, ROA, TAT, EPS, dan PER secara 
simultan berpengaruh signifikan terhadap return saham.

d. Widodo (2007) meneliti dengan judul "Analisis Pengaruh Rasio Aktivitas, Rasio Profitabilitas dan Rasio Pasar Terhadap Return Saham Syariah Dalam Kelompok Jakarta Islamic Index (JII) tahun 2003-2005, ”. Pada penelitian ini bertujuan untuk mengetahui pengaruh Return On Asset (ROA), Return On Equity (ROE), Earning Per Share (EPS), Price Book Value (PBV), Inventory Turnover (ITO), dan Total Asset Turn Over (TATO) terhadap return saham. Dari pengujian uji-t diperoleh hasil bahwa secara parsial variabel ROA, ROE, EPS, PBV, dan TATO berpengaruh signifikan terhadap return saham. Sedangakan variabel ITO tidak berpengaruh signifikan terhadap return saham.

Berdasarkan hasil uji-F variabel ROA, ROE, EPS, PBV, TATO, dan ITO secara serempak berpengaruh signifikan terhadap return saham.

e. Malintan (2013) meneliti dengan judul "Pengaruh Current Ratio (CR), Debt to Equity Ratio (DER), Price Earning Ratio (PER), dan Return on Asset (ROA) Terhadap Return Saham Perusahaan Pertambangan yang Terdaftar di Bursa Efek Indonesia Tahun 2005-2010" dengan variabel independen Current Ratio (CR), Debt to Equity Ratio (DER), Price Earning Ratio (PER), dan Return on Asset (ROA) terhadap return saham. Dari hasil pengujian uji-t diperoleh hasil variabel $\mathrm{CR}$ dan DER tidak berpengaruh signifikan terhadap return saham sedangkan variabel PER, dan ROA berpengaruh signifikan terhadap return saham. Dan hasil pengujian uji-F menunjukkan variabel $\mathrm{CR}$, DER, PER, dan ROA secara simultan tidak berpengaruh signifikan terhadap return saham.

f. Nathaniel (2008) meneliti dengan judul "Analisis Faktor-Faktor yang Mempengaruhi Return Saham" dengan variabel independen Debt to Equity Ratio (DER), Earning Per Share (EPS), Net Profit Margin (NPM), dan Price Book Value (PBV) terhadap return saham. Dari hasil pengujian uji-t diperoleh hasil variabel DER, EPS, dan NPM tidak berpengaruh signifikan terhadap return saham sedangkan variabel PBV berpengaruh signifikan terhadap return saham. Dan hasil pengujian uji-F menunjukkan variabel DER, EPS, NPM, dan PBV secara simultan berpengaruh signifikan terhadap return saham

\section{Hipotesis}

H1: Current Ratio (CR) berpengaruh secara signifikan terhadap return saham pada perusahaan Consumer Goods Industry yang tercatat di Bursa Efek Indonesia tahun 20122014.

H2: Debt to Equity Ratio (DER) berpengaruh secara signifikan terhadap return saham pada perusahaan Consumer Goods Industry yang tercatat di Bursa Efek Indonesia tahun 2012-2014

H3: Earning Per Share (EPS) berpengaruh secara signifikan terhadap return saham pada perusahaan Consumer Goods Industry yang tercatat di Bursa Efek Indonesia tahun 2012-2014.

H4: Total Asset Turnover (TATO) berpengaruh secara signifikan terhadap return saham pada perusahaan Consumer Goods Industry yang tercatat di Bursa Efek Indonesia tahun 2012-2014..

H5: Rasio keuangan yang terdiri dari CR, DER, EPS, dan TATO secara simultan berpengaruh signifikan terhadap return saham pada Consumer Goods Industry yang tercatat di Bursa Efek Indonesia tahun 2012-2014. 


\section{METODE PENELITIAN \\ Populasi dan Sampel}

Populasi dalam penelitian ini adalah perusahaan yang terdaftar dalam perusahaan sektor Consumers Goods Industry yang terdaftar di BEI tahun 20122014 sebanyak 38 perusahaan. Pengambilan sampel pada penelitian ini menggunakan teknik purposive sampling, dimana data yang dipilih berdasarkan kriteria tertentu yang sesuai dengan tujuan penelitian.

Sampel yang diambil sebanyal 11 perusahaan Consumer Goods Industry yang terdaftar di BEI dan memiliki saham aktif pada tahun 2012-2014 dari total keseluruhan perusahaan Consumer Goods Industry yaitu 38 perusahaan.

\section{Definisi Operasional}

1. Variabel Independen

Variabel independen (variabel bebas) merupakan variabel yang secara parsial dan simultan mempengaruhi variabel dependen (variabel terikat). Variabel independen dalam penelitian ini adalah:

\section{a. Current Ratio (CR) \\ Current ratio merupakan} kemampuan untuk membayar hutang yang segera harus dipenuhi, current ratio dihitung dengan cara membandingkan antara aktiva lancar dengan hutang lancar (Assakdiyah: 2006). Semakin besar perbandingan aktiva lancar dengan hutang lancar maka semakin tinggi kemampuan perusahaan meutupi kewajiban jangka pendeknya.

$$
C R=\frac{\text { Aktiva Lancar }}{\text { Utang Lancar }}
$$

\section{b. Debt to Equity Ratio (DER)}

Debt to Equity Ratio digambarkan dengan kemampuan modal sendiri yang dijadikan jaminan keseluruhan hutang. Darsono dan Ashari (2004) rasio ini menunjukkan persentase penyediaan dana oleh pemegang saham terhadap pemberi pinjaman. Semakin tinggi rasio, semakin rendah pendanaan perusahaan yang disediakan oleh pemegang saham.

$D E R=\frac{\text { Hutang Lancar }+ \text { Hutang Jangka Panjang }}{\text { Jumlah Modal Sendiri }}$

\section{c. Earning per Share (EPS)}

Earning per share (EPS) atau laba per lembar saham yaitu kemampuan perusahaan mencetak laba berdasarkan saham yang dipunyai (Hanafi dan Halim, 2005). Semakin tinggi nilai EPS menunjukkan semakin besar laba yang disediakan oleh pemegang saham.

$$
\text { EPS }=\frac{\text { Laba bersih setelah bunga dan pajak }}{\text { Total aset jumlah saham beredar }}
$$

\section{d. Total Asset Turn Over (TATO)}

Rasio ini digunakan untuk mengetahui efektivitas penggunaan aktiva dalam mengahasilkan penjualan. Semakin tinggi rasio ini semakin baik. Rasio ini juga mengukur seberapa efisien aktiva tersebut telah dimanfaatkan untuk memperoleh penghasilan (Prastowo, 1995).

$$
\text { TATO }=\frac{\text { Penjualan }}{\text { Total Aset }}
$$

2. Variabel Dependen

Variabel dependen (variabel terikat) merupakan variabel yang dipengaruhi oleh variabel independen (variabel bebas). Variabel dependen dalam peneltian ini adalah return saham. Return saham adalah pendapatan yang dinyatakan dalam presentase dari modal awal investasi. Pendapatan dalam investasi dalam saham ini meliputi keuntungan jual beli saham, di mana jika untung 
disebut capital gain dan jika rugi disebut capital loss. Di samping capital gain, investor juga akan menerima dividen tunai setiap tahunnya. Emiten akan membagikan dividen tunai dua kali setahun, di mana yang pertama disebut dividen interim yang dibayarkan selama tahun berjalan, sedangkan yang kedua disebut dividen final yang dibagikan setelah tutup tahun buku (Samsul, 2006).

\section{Uji Instrumen}

\section{Uji Asumsi Klasik}

Penyimpangan asumsi klasik terjadi dalam model regresi berganda yaitu:

a. Uji Normalitas

Uji Normalitas merupakan uji variabel dependen (Y) dan variabel independen $(\mathrm{X})$ pada persamaan regresi apakah berdistribusi normal atau tidak.

\section{b. Uji Heteroskedastisitas}

Uji heteroskedastisitas adalah ketidaksamaan varian dari residual dari obeservasi yang satu dengan yang lainnya. Dan jika varian memiliki varian yang sama maka tidak terjadi heteroskedastisitas.

\section{c. Uji Autokorelasi}

Uji autokorelasi untuk menguji apakah ada korelasi antara variabel pengganggu periode tertentu dengan variabel pengganggu periode sebelumnya pada model regresi berganda. Untuk menentukan ada tidaknya masalah autokerelasi dapat menggunakan uji Durbin-Watson (DW). Terjadi autokorelasi jika DW lebih rendah dari -2 (DW < -2), sebaliknya tidak terjadi autokerelasi jika mendekati angka $2(-2<\mathrm{DW}+2)$. Bisa juga dengan menggunakan Uji BreuschGodfrey yang disebut juga sebagai uji LM (Lagrange Multiplier), pengambilan keputusan dilakukan jika prob. Chi square > 0,05 maka tidak terjadi autokorelasi dan sebaliknya jika prob. Chi square < 0,05 maka terjadi autokorelasi.

\section{d. Uji Multikolinearitas}

Uji multikolinearitas untuk mengetahui adanya hubungan antar variabel bebas dalam model regresi linier berganda. Jika nilai VIF lebih kecil dari 10 maka tidak terjadi multikolineritas, sebaliknya jika nilai VIF lebih besar atau sama dengan 10 maka terjadi multikolineritas.

\section{Teknik Analisis Data}

1. Analisis Regresi Berganda Persamaan yang digunakan dalam penelitian ini yaitu:

$$
\begin{aligned}
& \gamma=\alpha+\beta_{1} \chi_{1}+\beta_{2} \chi_{2}+\beta_{3} \chi_{3}+\beta_{4} \chi_{4}+e \\
& \Gamma \quad \text { Keterangan: } \\
& \mathrm{A} \quad \text { return saham } \\
& \boldsymbol{\beta}_{1} \quad \text { : koefisien } \mathrm{x}_{1} \\
& \boldsymbol{\beta}_{2} \quad \text { : koefisien } \mathrm{x}_{2} \\
& \boldsymbol{\beta}_{3} \quad \text { : koefisien } \mathrm{x}_{3} \\
& \boldsymbol{\beta}_{4} \quad \text { : koefisien } \mathrm{x}_{4} \\
& \mathrm{x}_{1} \quad \text { : CR } \\
& \mathrm{x}_{2} \quad \text { : DER } \\
& \mathrm{x}_{3} \quad \text { EPS } \\
& \mathrm{x}_{4} \quad \text { TATO } \\
& e \quad \text { error }
\end{aligned}
$$

\section{Uji Hipotesis}

\section{Uji Parsial (Uji T)}

a. Uji t

Uji t digunakan untuk mengetahui pengaruh variabel independen secara parsial terhadap variabel dependen.

Langkah-langkah pengujian hipotesis dengan uji t:

1) Merumuskan hipotesis

2) Membandingkan nilai probabilitas $t$ hitung dengan alpha $=5 \%$

3) Pengeambilan keputusan:

Jika $\mathrm{p}<0,05$ maka menerima Ha Jika $p>0,05$ maka menerima H0 
2. Uji Simultan (Uji F)

Uji $\mathrm{F}$ digunakan untuk mengetahui pengaruh variabel independen secara simultan terhadap variabel dependen. Langkah-langkah pengujian hipotesis dengan uji F:

1) Merumuskan hipotesis

2) Membandingkan nilai probabilitas Fhitung dengan alpha $=5 \%$

3) Pengambilan keputusan:

Jika $\mathrm{p}<0,05$ maka menerima $\mathrm{Ha}$ Jika $\mathrm{p}>0,05$ maka menerima $\mathrm{HO}$

3. Uji Koefisien Determinasi

Uji koefisien determinasi (R2) digunakan untuk menjelaskan seberapa besar hubungan antara variabel independen terhadap variabel dependen secara bersama-sama. Jika R2 semakin mendekati nilai 1 maka kecocokan akan semakin baik.

\section{HASIL PENELITIAN DAN PEMBAHASAN}

\section{Statistik Deskriptif}

\begin{tabular}{|l|l|l|l|l|l|}
\hline & N & Minimum & Maximum & \multicolumn{1}{|c|}{ Mean } & $\begin{array}{c}\text { Std. } \\
\text { Deviation }\end{array}$ \\
\hline Cr & 33 & 0,00 & 2,05 & 0,8501 & 0,52211 \\
\hline Der & 33 & $-1,90$ & 0,54 & $-0,4412$ & 0,61249 \\
\hline Eps & 33 & 3,58 & 9,00 & 6,0042 & 1,63903 \\
\hline Tato & 33 & $-0,11$ & 1,06 & 0,3337 & 0,32416 \\
\hline Return & 33 & $-15,00$ & 148,00 & 37,4848 & 33,93754 \\
\hline $\begin{array}{l}\text { Valid N } \\
\text { (listwise) }\end{array}$ & 33 & & & & \\
\hline
\end{tabular}

Sumber: Data sekunder, diolah (2016)

Dari tabel diatas dapat dijelaskan bahwa rata-rata Current Ratio (CR) adalah 0,8501, artinya dari observasi selama periode penelitian perusahaan Consumer Good yang terdaftar di BEI mempunyai tingkat CR sebesar 0,8501 dan standar devisiasi 0,52211 artinya rata-rata penyimpangan sebesar 0,8501 .

Rata-rata Debt to Equity Ratio (DER) adalah 0,4412, artinya dari observasi selama periode penelitian perusahaan Consumer Good yang terdaftar di BEI mempunyai tingkat DER sebesar 0,4412 dan standar

devisiasi 0,61249 artinya rata-rata penyimpangan sebesar 0,61249 .
Rata-rata Earning per Share (EPS) adalah 6,0042, artinya dari observasi selama periode penelitian perusahaan Consumer Good yang terdaftar di BEI mempunyai tingkat EPS sebesar 6,0042 dan standar devisiasi 1,63903 artinya ratarata penyimpangan sebesar 1,63903.

Rata-rata Total Asset Turn Over (TATO) adalah 0,3337, artinya dari observasi selama periode penelitian perusahaan Consumer Good yang terdaftar di BEI mempunyai tingkat TATO sebesar 0,3337 dan standar

devisiasi 0,32416 artinya rata-rata penyimpangan sebesar 0,32416 .

Rata-rata return adalah 37,4848, artinya dari observasi selama periode penelitian perusahaan Consumer Good yang terdaftar di BEI mempunyai tingkat return sebesar 37,4848 dan standar devisiasi 33,93754 artinya ratarata penyimpangan sebesar 33,93754.

\section{Hasil Penelitian}

1. Hasil Uji Regresi Berganda

1. Uji Asumsi Klasik

\section{a. Uji Normalitas}

Model regresi yang baik adalah berdistribusi normal. Untuk menguji apakah data berdistribusi normal atau tidak dapat menggunakan alat uji Jarque-Bera (J-B) pada eviews. Pengambilan keputusan pada uji JB jika probabilty J-B lebih besar dari a 5\% (prob. J-B > 0,05), maka data berdistribusi normal. Begitu juga sebaliknya, apabila (prob. J-B $<0,05$ ) maka data berdistribusi tidak normal. Hasil uji normalitas pada penelitian ini besarnya prob. J-B 0,091609 yang berarti 0,091609>0,05 maka data pada penelitian ini berdistribusi normal.

Tabel 4.2

Hasil Uji Jarque-Bera

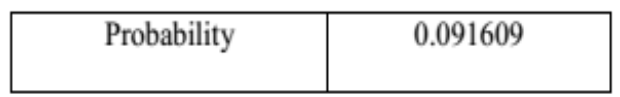

Sumber: Data sekunder, diolah (2016) 
b. Uji Heteroskedastisitas

Heteroskedastisitas adalah kondisi dimana nilai varians error untuk setiap data pengamatan tidak konstan atau $\operatorname{var}(1)=\sigma 2$. Uji heteroskedastisitas bertujuan untuk menguji apakah ada atau tidak ketidaksamaan varian dari residual dari obeservasi yang satu dengan yang lainnya. Dan jika varian memiliki varian yang sama maka tidak terjadi heteroskedastisitas. Dalam penelitian ini uji Probability 0.091609 heteroskedastisitas dilakukan dengan uji White pada eviews. Pengambilan keputusan dapat dilakukan jika Prob. Chi square (pvalue) $>0,05(\alpha)$ maka tidak terjadi heteroskedastisitas, begitu juga sebaliknya jika Prob. Chi square ( $\mathrm{p}$-value) $<0,05(\alpha)$ maka terjadi heteroskedastisitas. Tabel 4.3

Hasil Uji Heteroskedastisitas

\begin{tabular}{|c|c|}
\hline Prob. Chi-Square & 0.0921 \\
\hline
\end{tabular}

Sumber: Data sekunder, diolah (2016)

Dari hasil tampilan output eviews menunjukkan bahwa chi square ( $\mathrm{p}$-value) $>0,05$ maka pada hasil regresi ini memenuhi kaidah heteroskedastisitas

\section{c. Uji Autokorelasi}

Uji autokorelasi digunakan untuk menguji apakah ada korelasi antara variabel pengganggu periode tertentu dengan variabel pengganggu periode sebelumnya pada model regresi berganda.m Untuk uji autokorelasi dapat menggunakan uji Breusch-Godfrey dengan mengambil keputusan jika prob. Chi square $>0,05$ maka tidak terjadi autokorelasi sedangkan jika prob. Chi square $<0,05$ maka terjadi autokorelasi.

$$
\text { Tabel } 4.4
$$

Hasil Uji Autokorelasi

\begin{tabular}{|l|l|}
\hline Prob. Chi Square & 0,1892 \\
\hline
\end{tabular}

Sumber: Data sekunder, diolah (2016)

Dari tabel tampilan output eviews uji Breusch-Godfrey terlihat bahwa prob. Chi square > 0,05 maka tidak terjadi autokorelasi.

\section{d. Uji Multikolinearitas}

Uji multikolinearitas untuk mengetahui adanya hubungan antar variabel bebas dalam model regresi linier berganda. Jika variabel independen saling berkorelasi korelasi lebih dari 0,90 maka menunjukkan adanya gejala multikolinearitas.

$$
\text { Hasil Uji Multikolinearitas }
$$

\begin{tabular}{|l|l|l|l|l|}
\hline & CR & DER & EPS & TATO \\
\hline CR & 1.000000 & -0.821531 & 0.218693 & $-0,145767$ \\
\hline DER & -0.821531 & 1.000000 & -0.095783 & 0.261036 \\
\hline EPS & 0.218693 & -0.095783 & 1.000000 & 0.225617 \\
\hline TATO & -0.145767 & 0.261036 & 0.225617 & 1.000000 \\
\hline
\end{tabular}

Sumber: Data sekunder, diolah (2016)

Dari tabel 4.5 pengujian korelasi antar variabel independen di atas terlihat adanya nilai korelasi (derajat keeratan) yang rendah $(<0,90)$ antar variabel independen, maka hasil regresi ini tidak menunjukkan adanya gejala multikolinearitas

2. Hasil Uji Parsial (Uji T)

Uji t digunakan untuk mengetahui pengaruh variabel independen secara parsial terhadap variabel dependen. Pengujian hipotesis ini dilakukan dengan menggunakan signifikansi 0,05 $(\alpha=5 \%)$, penerimaan atau penolakan hipotesis dilakukan dengan membandingkan nilai probabilitas $\mathrm{p}$ value dengan alpha. Jika pvalue lebih kecil dari alpha maka menerima $\mathrm{Ha}$ sedangkan jika pvalue lebih besar dari alpha maka menerima $\mathrm{H} 0$.

Tabel 4.6

Hasil Uji Statistik t

\begin{tabular}{|l|l|l|l|l|}
\hline Variable & Coefficient & Std. Error & t-Statistic & Prob. \\
\hline C & 103.4960 & 21.45538 & 4.823777 & 0.0000 \\
\hline CR & -0.58654 & 18.92077 & -0.031000 & 0.9755 \\
\hline DER & 1.142935 & 16.17701 & 0.070652 & 0.9442 \\
\hline EPS & -10.85134 & 3.548199 & -3.058266 & 0.0049 \\
\hline TATO & 0.437348 & 18.06887 & 0.024205 & 0.9809 \\
\hline
\end{tabular}

Sumber: Data sekunder, diolah (2016) 
1) Pengujian Variabel Current Ratio (CR)

Pada tabel $4.6 \mathrm{di}$ atas diperoleh nilai probabilitas untuk variabel Current Ratio (X1) sebesar 0,9755 menunjukkan nilai probabilitas lebih besar dari signifikan (alpha) sebesar 0,05, maka H1 ditolak dan menerima H0. Dalam hal ini berarti Current Ratio tidak berpengaruh signifikan terhadap return saham pada perusahaan Consumer Good yang terdaftar di Bursa Efek Indonesia.

2) Pengujian Variabel Debt to Equity Ratio (DER)

Pada tabel 4.6 di atas diperoleh nilai probabilitas untuk variabel Debt to Equity Ratio (X2) sebesar 0,9442 menunjukkan nilai probabilitas lebih besar dari signifikan (alpha) sebesar 0,05, maka $\mathrm{H} 2$ ditolak dan menerima H0. Dalam hal ini berarti Debt to Equity Ratio tidak berpengaruh signifikan terhadap return saham pada perusahaan Consumer Good yang terdaftar di Bursa Efek Indonesia.

3) Pengujian Variabel Earning per Share (EPS)

Pada tabel 4.6 di atas diperoleh nilai probabilitas untuk variabel Earning per Share (X3) sebesar 0,0049 menunjukkan nilai probabilitas lebih kecil dari signifikan (alpha) sebesar 0,05, maka H3 diterima dan menerima Ha. Dalam hal ini berarti Earning per Share berpengaruh signifikan terhadap return saham pada perusahaan Consumer Good yang terdaftar di Bursa Efek Indonesia.

4) Pengujian Variabel Total Asset Turn Over (TATO)

Pada tabel 4.6 di atas diperoleh nilai probabilitas untuk variabel Total Asset Turn Over (X4) sebesar 0,9809 menunjukkan nilai probabilitas lebih besar dari signifikan (alpha) sebesar 0,05, maka $\mathrm{H} 4$ ditolak dan menerima H0. Dalam hal ini berarti Total Asset Turn Over tidak berpengaruh signifikan terhadap return saham pada perusahaan
Consumer Good yang terdaftar di Bursa Efek Indonesia.

3. Hasil Uji Simultan (Uji F)

Uji $\mathrm{F}$ digunakan untuk mengetahui pengaruh variabel independen secara simultan terhadap variabel dependen. Pengambilan keputusan pada uji $\mathrm{F}$ dilakukan dengan cara membandingkan pvalue dengan alpha $=5 \%$. Jika $p$-value lebih kecil dari alpha maka menerima Ha sedangkan jika p-value lebih besar dari alpha maka menerima $\mathrm{H} 0$.

Tabel 4.7

Hasil Uji statistik F

\begin{tabular}{|l|l|}
\hline Prob(F-statistic) & 0.050589 \\
\hline
\end{tabular}

Sumber: Data sekunder, diolah (2016)

Dari hasil tampilan output eviews dengan nilai probabilitas 0,50598 menunjukkan bahwa nilai probabilitas lebih besar dari alpha $=5 \%$ maka dapat disimpulkan bahwa variabel CR, DER, EPS, dan TATO secara simultan tidak berpengaruh terhadap return saham.

\section{Hasil Uji Koefisien Determinasi}

Uji koefisien determinasi (R2) digunakan untuk menjelaskan seberapa besar hubungan antara variabel independen terhadap variabel dependen secara bersama-sama. Jika R2 semakin mendekati nilai 1 maka kecocokan akan semakin baik.

Tabel 4.8

Hasil Uji ${ }^{2}$

\begin{tabular}{|c|c|}
\hline R-squared & 0.278689 \\
\hline
\end{tabular}

Sumber: Data sekunder, diolah (2016)

Dari tabel diatas maka dapat dijelaskan bahwa $\mathrm{R}$ square sebesar $27,8 \%$ return saham dapat dijelaskan oleh variabel Current Ratio (CR), Debt to Equity Ratio (DER), Earning per Share (EPS), dan Total Asset Turn Over (TATO). Sedangkan sisanya (100\%$27,8 \quad \%=72,2 \%) \quad$ dijelasakan oleh variabel lain. 


\section{Pembahasan}

Berdasarkan pada hasil output eviews, pada hipotesis pertama penelitian ini CR mempunyai pengaruh negatif dan tidak signifikan terhadap return saham pada perusahaan Consumer Good yang terdaftar di Bursa Efek Indonesia dengan nilai probabilitas 0,9755 . Karena nilai signifikansi $0,9755>0,05$ maka hipotesis pertama ditolak. Hal ini menjelaskan variabel $\mathrm{CR}$ tidak berpengaruh terhadap return saham. Hasil penelitian ini sesuai dengan penelitian yang dilakukan oleh Malintan (2013) dan Anastasia (2011) yang R-squared 0.278689 menyatakan CR tidak berpengaruh signifikan terhadap return saham. CR tidak berpengaruh terhadap return saham disebabkan karena jika CR terlalu rendah maka terjadi masalah dalam likuiditas perusahaan dan berakibat penurunan harga pasar dari saham perusahaan yang bersangkutan.

Pada hipotesis kedua penelitian ini

DER mempunyai pengaruh positif dan tidak signifikan terhadap return saham pada perusahaan Consumer Good yang terdaftar di Bursa Efek Indonesia dengan nilai probabilitas 0,9442 . Karena nilai signifikansi 0,9442>0,05 maka hipotesis kedua ditolak. Hal ini menjelaskan variabel DER tidak berpengaruh terhadap return saham. Hasil penelitian ini sesuai dengan penelitian yang dilakukan oleh Ulupui (2005) dan Nathaniel (2008) yang menyatakan DER tidak berpengaruh signifikan terhadap return saham. DER tidak berpengaruh signifikan terhadap return saham berarti hal ini mengindikasikan bahwa rasio utang tidak menyebabkan perubahan pada return saham. Perusahaan dengan tingkat hutang yang tinggi maka beban bunga akan semakin besar dan akan mengurangi keuntungan perusahaan.

Pada hipotesis ketiga penelitian ini EPS mempunyai pengaruh negatif dan signifikan terhadap return saham pada perusahaan Consumer Good yang terdaftar di Bursa Efek Indonesia dengan nilai probabilitas 0,0049 . Karena nilai signifikansi $0,0049<0,05$ maka hipotesis ketiga diterima. Hal ini menjelaskan variabel EPS berpengaruh terhadap return saham. Hasil penelitian ini sesuai dengan penelitian yang dilakukan oleh Widodo (2007) yang menyatakan EPS berpengaruh signifikan terhadap return saham. EPS yang semakin besar akan menunjukkan bahwa kemampuan perusahaan dalam menghasilkan laba bersih setelah pajak semakin meningkat. Dengan

meningkatnya laba bersih setelah pajak yang dihasilkan oleh perusahaan maka return yang akan diterima oleh para pemegang saham juga semakin meningkat. Tetapi EPS yang berpengaruh negatif kemungkinan selama

periode penelitian ini banyak terjadi guncangan ekonomi, misalnya kenaikan harga BBM, mata uang rupiah terhadap dollar berfluktuatif, harga pasar yang tidak tetap, dan sebagainya. Ini akan menyebabkan perusahaan mencari antisipasi yang aman dengan cara memperkecil EPS yang akan diterima investor.

Pada hipotesis keempat penelitian ini TATO mempunyai pengaruh positif dan tidak signifikan terhadap return saham pada perusahaan Consumer Good yang terdaftar di Bursa Efek Indonesia dengan nilai probabilitas 0,9809 . Karena nilai signifikansi 0,9809>0,05 maka hipotesis keempat ditolak. Hal ini menjelaskan variabel TATO tidak berpengaruh terhadap return saham. Hasil penelitian ini sesuai dengan penelitian yang dilakukan oleh Ulupui (2008) dan Anastasia (2011) yang menyatakan TATO tidak berpengaruh signifikan terhadap return saham. Dikarenakan kemungkinan rasio antar perusahaan berbeda karena perbedaan waktu perolehan asset. Misalnya, asset baru lebih efesien karena teknologi, tetapi jika keadaan saat inflasi maka asset akan menjadi lebih mahal. 


\section{KESIMPULAN DAN SARAN}

\section{Kesimpulan}

Berdasarkan analisis data yang sudah dilakukan, maka hasil yang dapat disimpulkan:

1. Hipotesis pertama (H1) ditolak yang menunjukkan bahwa Current Ratio (CR) tidak berpengaruh terhadap return saham pada perusahaan Consumer Good yang terdaftar di Bursa Efek Indonesia tahun 20122014. CR tidak berpengaruh terhadap return saham disebabkan karena jika $\mathrm{CR}$ terlalu rendah maka terjadi masalah dalam likuiditas perusahaan dan berakibat penurunan harga pasar dari saham perusahaan yang bersangkutan.

2. Hipotesis kedua (H2) ditolak yang menunjukkan bahwa Debt to Equity Ratio (DER) tidak berpengaruh terhadap return saham pada perusahaan Consumer Good yang terdaftar di Bursa Efek Indonesia51 tahun 20122014. DER tidak berpengaruh signifikan terhadap return saham berarti hal ini mengindikasikan bahwa rasio utang tidak menyebabkan perubahan pada return saham. Perusahaan dengan tingkat hutang yang tinggi maka beban bunga akan semakin besar dan akan mengurangi keuntungan perusahaan.

3. Hipotesis ketiga $(\mathrm{H} 3)$ diterima yang menunjukkan bahwa Earning per Share (EPS) berpengaruh terhadap return saham pada perusahaan Consumer Good yang terdaftar di Bursa Efek Indonesia tahun 2012- 2014. EPS berpengaruh berpengaruh signifikan terhadap return saham. EPS yang semakin besar akan menunjukkan bahwa kemampuan perusahaan dalam menghasilkan laba bersih setelah pajak semakin meningkat. Dengan meningkatnya laba bersih setelah pajak yang dihasilkan oleh perusahaan maka return yang akan diterima oleh para pemegang saham juga semakin meingkat.

4. Hipotesis ketiga (H4) ditolak yang menunjukkan bahwa Total Asset Turn Over (TATO) tidak berpengaruh terhadap return saham pada perusahaan Consumer Good yang terdaftar di Bursa Efek Indonesia tahun 20122014. TATO tidak berpengaruh signifikan terhadap return saham dikarenakan kemungkinan rasio antar perusahaan berbeda karena perbedaan waktu perolehan asset. Misalnya, asset baru lebih efesien karena teknologi, tetapi jika keadaan saat inflasi maka asset akan menjadi lebih mahal

\section{Saran}

Untuk peneliti selanjutnya, bisa ditambahkan variabel independen lain selain Current Ratio (CR), Debt to Equity Ratio (DER), Earning per Share (EPS), dan Total Asset Turn Over (TATO) yang mempengaruhi return saham, dapat memperluas objek penelitian, menambahkan penjelasan kondisi ekonomi makro selama periode penelitian dan perpanjang periode akan memungkinkan data menjadi lebih akurat

\section{DAFTAR PUSTAKA}

Anastasia, Nuri (2011) Pengaruh Kinerja Keuangan Terhadap Return Saham Pada Perusahaan Yang Terdaftar Di LQ 45 Selama Tahun 2006-2008. Skripsi. Yogyakarta: Universitas Ahmad Dahlan.

Assakdiyah, Salamatun. 2006. Manajemen Keuangan I. Universitas Ahmad Dahlan. Yogyakarta.

Darsono. Ashari. 2004. Pedoman Praktis Memahami Laporan Keuangan. Penerbit Andi. Yogyakarta.

Halim, Abdul. 2003. Analisis Investasi. Salemba Empat. Jakarta.

Hanafi dan Halim. 2005. Analisis Laporan Keuangan. UPP UMP YKPN. Yogyakarta. 
Harahap, Sofyan Syafri. 2007. Analisis Kritis Laporan Keuangan. PT Raja Grafindo Persada. Jakarta.

Jogiyanto, Hartono. 2014. Teori Portofolio dan Analisis Investasi. Edisi Kesembilan. BPFE. Yogyakarta.

Kasmir. 2013. Analisis Laporan Keuangan. Rajawali Pers. Jakarta.

Kurniawan, Septiana Hadi. 2013. Pengaruh Economic Value Added (EVA) dan Profitabilitas Perusahaan Terhadap Return saham. Skripsi. Yogyakarta: Universitas Ahmad Dahlan.

Malintan, Rio. 2013. Pengaruh Current Ratio (CR), Debt to Equity Ratio (DER), Price Earning Ratio (PER), dan Return on Asset (ROA) Terhadap Return Saham Perusahaan Pertambangan yang terdaftar di Bursa Efek Indonesia Tahun 20052010. Jurnal Akuntansi. Malang: Universitas Brawijaya.

Martalena. Maya Malinda. 2011. Pengantar Pasar Modal. Penerbit Andi. Yogyakarta.

Munawir, S. 2004. Analisis Laporan Keuangan. Edisi Keempat. Liberty. Yogyakarta.

Nathaniel, Nicky. 2008. Analisis FaktorFaktor yang mempengaruhi Return Saham. Tesis Manajemen. Semarang: Universitas Diponegoro.

Prastowo, Dwi. 1995. Analisis Laporan Keuangan Konsep dan Aplikasi. UPP AMP YKPN. Yogyakarta.

Riyani, Ica. 2011. Analisis Pengaruh Rasio Profitabilitas terhadap Return Saham pada Perusahaan LQ45 yang Terdaftar di Bursa Efek Indonesia. Skripsi. Yogyakarta: Universitas Ahmad Dahlan.

Samsul, Mohamad. 2006. Pasar Modal dan Manajemen Portofolio. Erlangga. Tandelilin, Eduardus. 2001. Analisis Investasi dan Manajemen Portofolio. Edisi Pertama. BPFE. Yogyakarta.

Ulupui, IGKA. 2005. Analisis Pengaruh Rasio Likuiditas, Leverage, Aktivitas, dan Profitabilitas
Terhadap Return Saham (Studi pada Perusahaan Makanan dan Minuman dengan Kategori Industri Barang Konsumsi di Bursa Efek Jakarta). Jurnal Akuntansi. Bali: Universitas Udayana.

Untung, Budi. 2011. Hukum Bisnis Pasar Modal. Penerbit Andi. Yogyakarta.

Wahyuningtyas, Try. 2013. Analisis Pengaruh Rasio Profitabilitas dan Economic Value Added terhadap Return Saham. Skripsi. Yogyakarta: Universitas Ahmad Dahlan.

Widodo, Saniman. 2007. Analisis Pengaruh Rasio Aktivitas, Rasio Profitabilitas, dan Rasio Pasar terhadap Retun Saham Syariah Dalam Kelompok Jakarta

Islamic Index (JII) Tahun 2003-2005. Tesis Manajemen. Semarang: Universitas Diponegoro.

Wulandari, Endri. 2012. Pengaruh Kinerja Keuangan terhadap Return Saham Studi Pada Perusahaan Manufaktur yang Terdaftar di Bursa Efek Indonesia. Skripsi. Yogyakarta: Universitas Ahmad Dahlan.

www.idx.co.id

www.sahamoke.com 